\title{
Immune interferon in serum and synovial fluid in rheumatoid arthritis and related disorders
}

\author{
M. DEGRE , ${ }^{1}$ O.J. MELLBYE, ${ }^{2}$ AND O. CLARKE-JENSSEN ${ }^{2}$ \\ From ${ }^{1}$ Wilhelmsens Institute of Bacteriology, ${ }^{2}$ Institute of Immunology and Rheumatology, Rikshospitalet, \\ Oslo Sanitetsforening Rheumatism Hospital, and ${ }^{1}$ National Institute of Public Health, Department of Virology, \\ Oslo, Norway
}

SUMMARY Moderate titres of antiviral activity were demonstrated in $48-58 \%$ of sera obtained from patients suffering from seropositive and seronegative rheumatoid arthritis (RA), psoriatic arthritis, Reiter's syndrome, ankylosing spondylitis, and juvenile rheumatoid arthritis. Sera from blood donors and from patients with various noninflammatory diseases were positive in $16 \%$ of cases. The activity was species-specific, mediated by the homologous cells, and destroyed by treatment with trypsin and exposure to $\mathrm{pH} 2$. Antibodies against human IFN- $\alpha$ did not neutralise the activity. These characteristics are compatible with those of IFN- $\gamma$ or immune interferon. Neither the presence nor the titre of IFN was correlated with disease activity defined by concentration of C-reactive protein, C3 concentration, and erythrocyte sedimentation rate. IFN- $\gamma$ was present in 4 of 10 synovial fluids from patients with RA. The titre in one of these was higher than in the corresponding serum, indicating local production in the rheumatoid joint.

Stimulation of lymphocyte blastogenesis and proliferation may be accompanied by induction of interferon (IFN). Such stimuli include either nonspecific mitogens ${ }^{1}$ or cellular immune reactions by specific antigens. $^{23}$ The immune-specific nature of the response has been demonstrated. ${ }^{4}$ Similarly, IFN production can be shown in mixed cultures of tumour cells and lymphocytes ${ }^{5}$ and tumour cells and macrophages. ${ }^{6}$ The IFN produced by the stimulated lymphocytes differs in several respects from the classical virus-induced interferons, for instance in sensitivity to treatment at low $\mathrm{pH}$, stability at $56^{\circ} \mathrm{C}$, cross-species activity, and antigenic specificity. The former type is termed IFN- $\gamma$, previously called 'immune' or type II, in contrast to the virus-induced IFN- $\alpha$ and IFN- $\beta$, previously called type I interferons.

Following the original observation that IFN- $\gamma$ are produced in vivo in response to mitogens and specific antigens it has been reported that circulating IFN- $\gamma$ can be detected in patients with autoimmune diseases as rheumatoid arthritis, systemic lupus erythematosus, and Sjögren's syndrome. ${ }^{7}$ In the present communication we confirm and extend these observations, which give further evidence for cellular

Accepted for publication 15 October 1982.

Correspondence to Professor M. Degré, Department of Virology, National Institute of Public Health, Postuttak Oslo 1, Norway. immune reactions in these diseases and may represent possible pathogenetic factors.

\section{Materials and methods}

Patients and controls. Sera were obtained from the following groups: 31 patients with classical or definite seropositive rheumatoid arthritis (RA) according to the American Rheumatism Association criteria, ${ }^{4} 16$ with seronegative RA, 12 with psoriatic arthritis or Reiter's syndrome, 19 with ankylosing spondylitis (SA), and 22 with juvenile rheumatoid arthritis (JRA) according to the criteria of Brewer $e t$ $a l .{ }^{8}$ All were admitted to the Oslo Sanitetsforening Rheumatism Hospital. Sera from 27 patients with various noninflammatory diseases, including 15 with osteoarthritis from Lillehammer Sanitetsforening Rheumatism Hospital, served as controls, together with sera from 50 randomly selected healthy blood donors obtained from Norwegian Red Cross Blood Centre, Oslo. Synovial fluid/serum pairs were obtained from $10 \mathrm{RA}$ patients at Oslo Sanitetsforening Rheumatism Hospital

The blood was collected in sterile tubes, and sterile equipment was used for further handling. The samples were stored at $-70^{\circ} \mathrm{C}$ until testing.

The patients were receiving treatment with salicylates and related drugs, chloroquine, 
D-penicillamine, gold thiomalate, or glucocorticosteroids.

$C$-reactive protein $(C R P)$ was measured by single radial immunodiffusion ${ }^{9}$ with $L C$-Partigen plates from Behringwerke AG, Marburg, West Germany.

$C 3$ was quantitated by nephelometry with antisera from Behringwerke AG.

Erythrocyte sedimentation rate (ESR) was measured by standard haematological techniques in the routine laboratory at Oslo Sanitetsforening Rheumatism Hospital.

Total protein in synovial fluids was measured by the Folin method. ${ }^{10}$

Statistical evaluation was performed by the FisherIrwin exact test. ${ }^{11}$

Interferon. Interferon activity was tested by an infectivity inhibition micromethod ${ }^{12}$ employing human embryonic lung fibroblast cells in their 5-15th passage, and vesicular stomatitis virus as challenge virus. The antiviral activity was calculated as the reciprocal of the highest dilution preventing development of cytopathogenic effect in $50 \%$ of the wells at the time when control cells were completely destroyed. One unit of the international standard preparation (69/19) was equivalent to $1-1 \cdot 3$ units in our assay system. In view of previous experience in our laboratory ${ }^{13}$ and that of others ${ }^{7}$ only sera containing antiviral activity with titres of 16 or higher were considered positive.

To characterise the antiviral activity, representative positive samples were tested for activity on heterologous cells, with trypsin, and by heat sensitivity. Samples were also adjusted to $\mathrm{pH} 2$ for 2 days and then tested in the same system. Adjustment to $\mathrm{pH} 2$ eliminated the antiviral activity of a Hu IFN- $\gamma$ preparation received from Dr Marc De Ley, University of Louvain, Belgium, but did not affect the activity of a $\mathrm{Hu}$ IFN- $\alpha$ preparation given to us by Dr Kari Cantell, National Institute of Public Health, Helsinki, Finland.

Specific antihuman interferon globulin, prepared against $\mathrm{Hu}$ IFN- $\alpha$ was obtained from the Antiviral Programme of National Institute of Allergy and Infectious Diseases, Bethesda, Maryland, USA.

\section{Results}

The presence of antiviral activity in sera from different groups of patients is shown in Table 1. It was more frequently detected in sera from all patient groups than from controls. There was no difference in frequency between the different patient categories. Titres were generally moderate; in blood donors all positive cases were below 35 , in the patients' sera somewhat higher, some up to 60 . The titres did not differ between any specific group of patients.
Table 1 Interferon titre in sera from various rheumatic diseases

\begin{tabular}{|c|c|c|c|}
\hline Diagnosis & $\begin{array}{l}\text { No. positive } \\
\text { (titre } \geq 16)\end{array}$ & $\begin{array}{l}\text { Total no. } \\
\text { examined }\end{array}$ & $\begin{array}{l}\text { Percentage } \\
\text { positive }\end{array}$ \\
\hline Seropos. RA & 15 & 31 & 48 \\
\hline Seroneg. RA & 7 & 16 & 44 \\
\hline \multicolumn{4}{|l|}{ Psoriatic arthritis/ } \\
\hline Reiter's syndrome & 7 & 12 & 58 \\
\hline Ankylosing spondylitis & 10 & 19 & 53 \\
\hline JRA & 12 & 22 & 55 \\
\hline \multicolumn{4}{|l|}{ Controls: } \\
\hline $\begin{array}{l}\text { Various non- } \\
\text { inflammatory diseases }\end{array}$ & & 27 & 4 \\
\hline Blood donors & 8 & 50 & 16 \\
\hline
\end{tabular}

For all the rheumatic diseases the frequency observed was significantly higher than that in both the control groups (Fisher's exact test, $\mathrm{p}<0.05$ ).

The antiviral activity was species-specific; no activity was obtained when tested in mouse L-929 cells. Further, the antiviral activity was trypsin-sensitive, and it did not neutralise directly the infectivity of vesicular stomatitis virus. Treatment of positive sera at $\mathrm{pH} 2$ for 2 days eliminated the antiviral activity in 6 randomly selected sera containing high activity, suggesting that the interferon is most likely IFN- $\gamma$. The antiviral activity in the same sera was not neutralised by the IFN- $\alpha$ antiserum. Unfortunately we did not have IFN- $\gamma$ antiserum at our disposal.

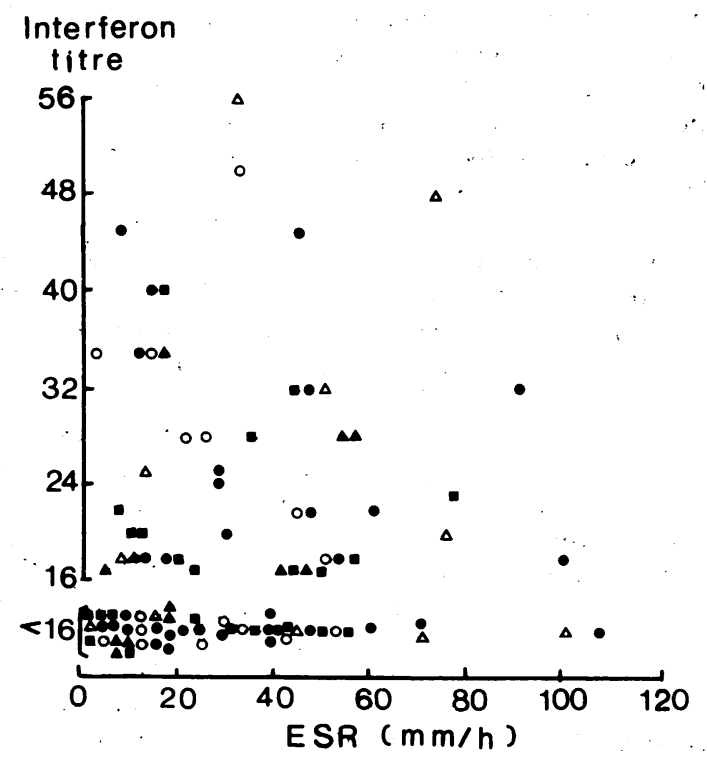

Fig. 1 Correlation between interferon titre and ESR in sera from patients with seropositive $R A(0)$, seronegative $R A$ (O), psoriatic arthritis/Reiter's syndrome ( $\Delta)$, ankylosing spondylitis ( $\triangle$ ), and JRA (ם). 
Table 2 Association between interferon titre and various laboratory parameters for disease activity in sera from various rheumatic diseases

\begin{tabular}{llll}
\hline Parameter & & \multicolumn{2}{l}{$\begin{array}{l}\text { Number of sera with interferon } \\
\text { titre }\end{array}$} \\
\cline { 3 - 4 } & & $<16$ & $\geq 16$ \\
\hline ESR & $\leq 15 \mathrm{~mm} / \mathrm{h}$ & 19 & 12 \\
& $>15 \mathrm{~mm} / \mathrm{h}$ & 32 & 32 \\
CRP & $\leq 10 \mathrm{mg} / \mathrm{l}$ & 27 & 32 \\
& $>10 \mathrm{mg} / \mathrm{l}$ & 22 & 29 \\
C3 & $\leq 1.3 \mathrm{~g} / 1$ & 40 & 37 \\
& $>1.3 \mathrm{~g} / \mathrm{l}$ & 9 & 14
\end{tabular}

Statistical testing of association by Fisher's exact test for all parameters showed no association with high or low interferon titres $(p>0 \cdot 10)$.

Table 3 Synovial fluid/serum ratios for interferon titre and total protein concentration in patients with $R A$

\begin{tabular}{lll}
\hline & IFN titre & Total protein \\
\hline Patient A & 1.6 & $0 \cdot 3$ \\
Nine other patients & $0.3-1.0$ & $0 \cdot 3-0.8$ \\
\hline
\end{tabular}

Neither the presence of IFN nor the titres of the positive samples were positively or negatively correlated with disease activity in any patient groups as measured by ESR, complement factor C3, or CRP concentration (Fig. 1 and Table 2). C3 usually behaves as an acute-phase reactant in these diseases ${ }^{14}$ but may be reduced in severe cases.

Interferon activity was tested in synovial fluid and in corresponding serum for 10 patients with RA in order to see whether there was a local production in the rheumatoid joint. Seven sera and 4 synovial fluids showed interferon activity over 16 . They were all $\mathrm{pH}$ 2 -sensitive. In one pair the titre in the synovial fluid, 28 , was higher than that in the serum, 18 , suggesting local production in the joint. In the 3 other positive pairs the serum titres were higher than those in synovial fluid. Taken together with the synovial protein ratio to serum protein concentrations (Table 3 ) this suggests that at least in one out of the 4 cases interferon was probably produced in the joint, while the others can be explained by passive influx into the joint of systemically produced interferons.

No relation was found between the IFN- $\gamma$ titres and treatment with glucocorticosteroids, either alone or in combination with azathioprine or penicillamine. Among the 15 patients who were on such treatment 9 $(60 \%)$ had an IFN- $\gamma$ titre of $>16$. Neither was there any relation to the other forms of treatment (data not shown).

\section{Discussion}

The present data confirm the earlier report ${ }^{7}$ that circulating antiviral activity can frequently be demonstrated in the serum of patients suffering from rheumatoid arthritis. We also found such activity in various other rheumatoid diseases not previously studied for this factor. In contrast, in control persons, represented by healthy blood donors and various noninflammatory joint diseases such as osteroarthritis, it was only rarely present. The various inflammatory rheumatoid diseases represented in our study were similar in this respect.

The antiviral activity was characterised by standard criteria, as species specificity-i.e., activity only on human cells. The activity was destroyed by trypsin treatment, and by incubation at $56^{\circ} \mathrm{C}$ for 2 hours. Extracellular VSV was not neutralised by sera containing antiviral activity. Furthermore it was sensitive to exposure to $\mathrm{pH} 2$ and was not neutralised by antihuman IFN- $\alpha$ globulin. These data strongly suggest that the activity is due to IFN- $\gamma$. However, the data are not conclusive, for other antiviral serum factors are not excluded. The presence of IFN- $\gamma$ is consistent with the original observation by Hooks $e t$ $a l .^{7}$ that IFN in rheumatoid arthritis and systemic lupus erythematosus is of the IFN- $\gamma$ type, but it does not support a later report from the same group that IFN- $\alpha$ is also present. ${ }^{15}$

There is a consensus that IFN- $\gamma$ are produced by cells involved in the immune system. ${ }^{16}$ The main producers are apparently different lymphocyte populations, probably in co-operation with accessory cells such as monocytes and macrophages, ${ }^{17}$ and possibly macrophages in co-operation with other nonimmune cells. $^{6}$ The bulk of the data suggest that the main producers are $\mathrm{T}$ lymphocytes, but B lymphocytes have also been incriminated. ${ }^{18} \mathrm{~A}$ wide variety of substances may induce production, ${ }^{19}$ mitogens such as phytohaemagglutinin (PHA), concanavalin-A (con-A), pokeweed mitogen (PWM), streptolysin O, and staphylococcal enterotoxin, as well as antigens in sensitised cells, including bacterial, viral, and mycoplasmal antigens. In addition IFN- $\gamma$ can be elicited by allogeneic cells, tumour cells, and antibodies directed against cell surface components. Recently several groups ${ }^{20-22}$ have reported that the monoclonal antibody OKT3, specific for a human T cell surfaceantigen molecule, effectively induced IFN- $\gamma$ production, as did heterologous antithymocyte globulin and antilymphocytic serum.

We do not know the origin of IFN- $\gamma$ in our patients suffering from rheumatoid arthritis and related disorders. It is possibly a result of sensitised $T$ cells reacting with an unknown antigen. ${ }^{23}$ It is also, however, well known that autoantibodies partly directed 
against lymphocytes and immune complexes can frequently be demonstrated in the serum of such patients. It is possible that such antibodies stimulate interferon production in sensitised lymphocytes. Lymphokines regularly co-produced with IFN- $\gamma$ have been demonstrated in peripheral blood and synovial fluids of patients with rheumatoid arthritis. ${ }^{24} 25$

In one of our patients the interferon titres in the synovial fluid were higher than in the serum, even when the relative protein concentration is taken into consideration, indicating that the interferon may have been produced in the affected joint. More systematic studies are required to define the site of interferon production.

We found no correlation between the presence of interferon in the serum or interferon titres on the one hand and disease activity as measured by laboratory tests on the other. This is somewhat surprising, since Hooks et al. ${ }^{7}$ reported a correlation between disease activity and increased interferon titres in cases of systemic lupus erythematosus (SLE). However, our patients are not directly comparable with theirs, as we did not include SLE patients in our investigation. It is also possible that our data show a difference in base levels, and that even in our patients there is a variation of interferon concentration which is correlated with the course of disease. This question can be answered only by a longitudinal study of well defined patient groups.

At present we can only theorise on the possible role of interferon in these conditions. We know that it may alter several immune functions, either enhancing or depressing them according to timing and concentration. The stimulatory effect of interferon on NK cell activity may be important in this context, but NK cell activity does not seem to be increased in RA and JRA. ${ }^{26}$ Endogenous interferon is largely responsible for the manifestations of acute lympocytic choriomeningitis virus disease in suckling mice, ${ }^{27}$ and it accelerates the progression of autoimmune disease in New Zealand black mice, ${ }^{28}$ indicating that it may have a crucial role in several immunological diseases.

We are indebted to Dr H. K. Brath, Lillehammer Sanitetsforening Rheumatism Hospital, for providing sera from patients with osteoarthritis, and to the Norwegian Hydro Company for financial support. The study was also supported by the Norwegian Association for Fighting Cancer.

\section{References}

1 Wheelock E F. Interferon-like virus-inhibitor induced human leukocytes by phytohemagglutinin. Science $1965 ; 149$ : 310-1.

2 Green J A, Cooperband S R, Kibrick S. Immune stimulation of interferon in human leukocyte cultures by non-viral antigens. Ann NY Acad Sci 1970; 173: 736-40.

3 Stinebring W R, Absher P M. Production of interferon following an immune reponse. Ann NY Acad Sci 1970; 173: 714-25.
4 Ropes M W, Bennet G A, Cobb S, Jacox R, Jessar R A. 1958 revision of diagnostic criteria for rheumatoid arthritis. Bull Rheum Dis 1958; 9: 175-6.

5 Trinchieri G, Santoli D. Anti-viral activity induced by culturing lymphocytes with tumour-derived or virus-transformed cells: enhancement of human natural killer cell activity by interferon and antagonistic inhibition of susceptibility of target cells to lysis. J Exp Med 1978; 147: 1314-33.

6 Olstad R, Degré M, Seljelid R. Production of immune interferon (type II) in cocultures of mouse peritoneal macrophages and syngeneic tumor cells. Scand J Immunol 1981; 13: 605-8.

7 Hooks J J, Moutsopoulos H M, Geis S A, Stahl N I, Decker J L, Notkins A L. Immune interferon in the circulation of patients with autoimmune disease. $N$ Engl J Med 1979; 301: 5-8.

8 Brewer E J, Bass J, Baum J, et al. Current proposed revision of JRA criteria. Arthritis Rheum 1977; 20: 195-9.

9 Mancini G, Carbonara A O, Heremans J F. Immunochemical quantitation of antigen by single radial diffusion. Immunochemistry 1965; 2: 235-54.

10 Lowry O H, Rosenbourgh N J, Farr A L, Randall R J. Protein measurement with the Folin phenol reagent.J Biol Chem 1951; 193: 265-75.

11 Diem K, ed. Documenta Geigy. Scientific Tables. 6th ed. Basle: Geigy, 1962: 779: 119-23.

$12 \mathrm{Dahl} \mathrm{H}$, Degré M. A micro assay for mouse and human interferon. Acta Pathol Microbiol Scand $[B]$ 1972; 80: 863-70.

13 Degré $M$, Dahl H, Vandvik B. Interferon in the serum and cerebrospinal fluid in patients with multiple sclerosis and other neurological disorders. Acta Neurol Scand i 976; 53: 152-6.

14 Pepys M B. Acute phase phenomena. In: Cohen A S, ed. Rheumatology and immunology. New York: Grune and Stratton, 1979: 85-9.

15 Hooks H J, Jordan G W, Cupps T, Moutsopoulos H M, Fauci A S, Notkins A L. Multiple interferons in the circulation of patients with systemic lupus erythematosus and vasculitis. Arthritis Rheum 1982; 25: 396-400.

16 Epstein L B, Weil J, Lucas D O, Cox D R, Epstein C J. The biology and properties of interferon-gamma. An overview, studies of production by $\mathrm{T}$ lymphocyte subsets, and analysis of peptide synthesis and antiviral effects in trisomy 21 and diploid human fibroblasts. In: De Maeyer E, Galasso G, Schellekens $\mathrm{H}$. eds. The biology of the interferon system. Amsterdam: Elsevier/North Holland, 1981: 247-56.

17 Epstein L B. Effects of interferon on the immune response in vitro and in vivo. In: Stewart II W E, ed. Interferon and their actions. Cleveland: CRC Press, 1977: 91-132.

18 Epstein L B, Kreth H W, Herzenberg L A. Fluorescene activated sorting of human $T$ and $B$ lymphocytes. II. Identification of the cell type responsible for interferon production and cell proliferation in response to mitogens. Cell Immunol 1974; 12: 407-21.

19 Epstein L B. Mitogen and antigen induction of interferon in vitro and in vivo. Tex Rep Biol Med 1978; 35: 42-56.

20 Testa D, Chang T-W, Perry L, Kung P C, Goldstein G. Cellular origin of human gamma interferon induced by OKT. 3 monoclonal antibody. J Clin Hematol Oncol 1981; $11: 115$.

21 Pang R H L, Yip Y K, Vilček J. Immune interferon induction by a monoclonal antibody specific for human T-cells. Cell Immunol 1981; 64: 304-11.

22 Wussow $P$ von, Platsoucas C D, Wiranowska-Stewart $M$, Stewart II W E. Human $\gamma$ interferon production by leukocytes induced with monoclonal antibodies recognizing $\mathrm{T}$ cells. $J$ Immunol 1981; 127: 1197-200.

23 Morris A G, Lin Y-L, Askonas B A. Immune interferon release when a cloned cytotoxic T-cell line meets its correct influenzainfected target cell. Nature 1982; 295: 150-2.

24 Granger G A, Shimizu I, Harris L, et al. Detection of lymphotoxins in vivo. I. Specific identification of short-lived LT activity in the plasma of various human patients employing rabbit antihuman LT sera in vitro. Clin Immunopathol 1978; 10: 104-15. 
25 Stastny $\mathrm{P}$, Rosenthal $\mathrm{M}$, Andreis $\mathrm{M}$, et al. Lymphokines in the rheumatoid joint. Arthritis Rheum 1975; 18: 237-43.

26 Dobloug J H, Førre $\emptyset$, Kvien T K, Egeland T, Degré M. Natural killer (NK) cell activity of peripheral blood, synovial fluid and synovial tissue lymphocytes from patients with rheumatoid arthritis and juvenile rheumatoid arthritis. Ann Rheum Dis 1982; 41: $490-4$.
27 Rivière Y, Gresser I, Guillon J-C, et al. Severity of lymphocytic choriomeningitis virus disease in different strains of suckling mice correlates with increasing amounts of endogenous interferon.J Exp Med 1980; 152: 633-40.

28 Engleman E G, Sonnenfeld G, Dauphinee M, et al. Treatment of NZB/NZW $F_{1}$ hybrid mice with Mycobacterium bovis strain BCG and type II interferon preparations accelerates autoimmune disease. Arthritis Rheum 1981; 24: 1396-402. 